\title{
Effect Of Garlic (Allium Sativum) And Fenugreek (Trigonella Foenum-Graecum) Extracts On Aspergillus Fumigatus
}

\author{
Ali A. S. AI-Mayah \\ Department of Pathology, College of Veterinary Medicine, \\ University of Basrah,
}

Summary

The effect of garlic (Allium Sativum) \& fenugreek (Trigonella foenum-graecum) aqueous extracts (GE \& FE) were studied with respect to their antifungal activity against Aspergillus fumigatus. Garlic extract (GE) at 5\% was completely inhibit the growth of the test fungus in the agar plate method whether the extract mixed with or spreaded on the surface of the medium. Fenugreek extract (FE) at 10\% did not exhibit any effect against this fungus in the sane method. Garlic extract (GE) \& garlic chips (GC) inhibited the growth of Aspergillus fumigatus inoculated in poultry feed samples. The viable spore count per gram of feed treated with garlic was less than control feed samples. Garlic extract (GE) was more effective than garlic chips (GC). Fenugreek extract (FE) at 10\% (did not inhibit the growth of the same fungus and the viable spore count was the same as the control.

$$
\begin{aligned}
& \text { تأثير المستخلص المائي للثوم والحلبة على الرشاشيات الدخناء } \\
& \text { علي عبد سهم المياح } \\
& \text { فرع الأمراض / كلية الطب البيطري / جامعة البصرة }
\end{aligned}
$$

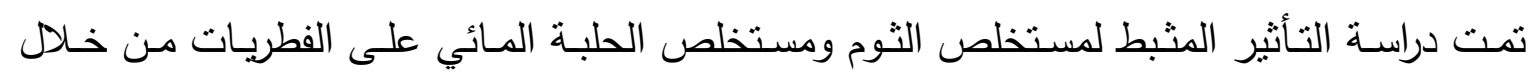
استخدام الرشاشيات الدخناء لهذا الغرض حيث تبين أن 5\% من المستخلص المائي للثوم قد ثبط نمو هذه

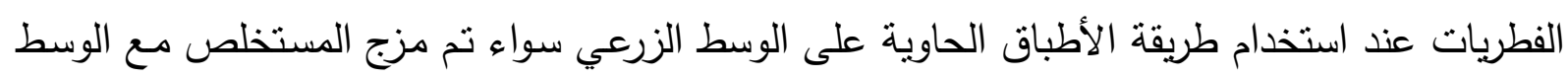

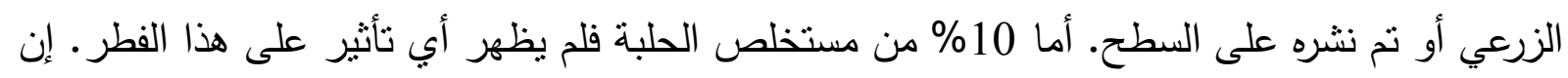

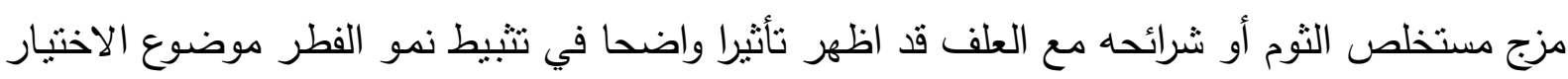
من خلال عدد الابواغ الفعالة في 1 غم من علف الدواجن الملوث بالفطر بالمقارنة مع السيطرة. إن تأثنير

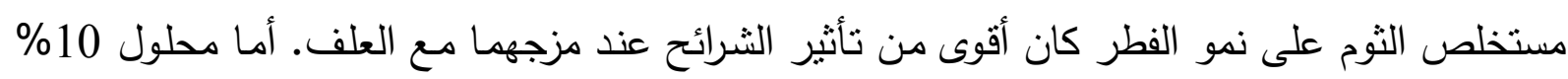

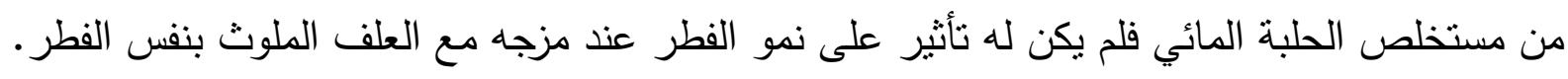




\section{Introduction}

Ancient Arabs have been used many kinds of plants \& herbs as medicine for curing different diseases. Garlic (Allium sativum) \& seeds of fenugreek (Trigonella foenum-graecum)are some of the most important plants which were used (Al-Hassan \& Al- Gailany, 1985 \& Riggs et al .,1997).

Garlic is utilized as folk medicine in many countries for its antimicrobial \& other beneficial properties \& the efficacy of its extract has been studied against the genus Aspergillus (Pai \& Platt, 1995).

Antidermatophytic activity of' the aqueous extract of' garlic was investigated against several clinical isolates of dermatophytes \& it could be used as an effective antidermatophytic agent (Veugopal \& Veugopal, 1995).

Growth of many species of zoopathogenic fungi was shown to be inhibited by aqueous extracts of garlic bulbs (Appleton \& Tansey, 1975).

Fenugreek seeds, which is called Helba in Arabic, were used as medicine for curing different diseases (A1-Hassan \& Al- Gialany, 1985 \& Patil el al., 1997).

In light of data reported by others on the inhibitory effects of spices on micro organisms, experiments were designed to determine the effects of aqueous garlic \& fenugreek extracts on Aspergillus fumigatus isolated from naturally infected chicks.

\section{Materials And Methods}

Garlic extract was prepared by grinding $5 \mathrm{gm}$ of garlic bulbs in $100 \mathrm{ml}$ sterile distilled water to obtain 5\% solution at w/v ratio. Grinding was carried out by electric blender until homogenization. The solution was allowed to stand for 15 min then filtered through sterile filter paper \& used immediately (Basim, 1979).

Fenugreek, extract was prepared by boiling (FE1) or by crushing \& boiling (FE2) $10 \mathrm{gm}$ of fenugreek seeds in $100 \mathrm{ml}$ sterile distilled water for about $2 \mathrm{~min}$. to obtain 10\% solution at w/v ratio (Patil et al., 1997).

Aspergillus fumigatus has been isolated from air sac of naturally infected bird \& was maintained on Potato-Dextrose Agar (PDA). The bird exhibited signs \& lesions of' aspergillosis. A sterile sample was taken from the lesion in the air sacs after post mortem \& exposure the internal organs of this bird. The sample was cultured on PDA (Carter, 1984 \& Domermuth \& Gross, 1975).

To investigate the antifungal activity of aqueous garlic \& fenugreek extracts (GE \& FE) against A. fumigatus, agar plate test was used. Petri plates were poured with PDA medium \& $0.5 \mathrm{ml}$ of each extract was either added to form a thin layer on the medium surface or mixed with medium before poured in plate. A disc ( $1 \mathrm{~cm}$ diameter) of the fungus was taken from 7 day old culture with a sterile cork borer $\&$ placed in the center of each petri-dish. Each test was 
performed in doublicate. For control \& comparison, a plate was treated with 0.2 $\mathrm{ml}$ sterile distilled water \& another was treated with $0.2 \mathrm{ml}$ Nystatine solution (100 000 I.U/ ml ITALFARMACO, MILANO-ITALY). All dishes were incubated at 25' $\mathrm{C}$ for 7 days. Visual estimation of fungal growth was noticed daily until the day of incubation (El-Kady el al.,1993).

For investigation the antifungal activity of garlic \& fenugreek in poultry feed, GE, GC, FE1, \& FE2 were mixed with feed samples which inoculated with the test fungus. To prepare garlic chips (GC), garlic cloves were cut into small pieces with the help of sterile Grater 3 instead of mortar \& pestil (Prassad \& Sharma, 1981).

The inoculum of A. fumigatus was prepared by making suspension of 7day-old culture in normal saline. The viable spore count of the inoculum was determined by standard pour plate method (Qasem , 1996).

A quantity $(1 / 4 \mathrm{~kg})$ of commercial poultry feed was sterilized by autoclaving at 121 ' $\mathrm{C}$ for half an hour. Thereafter $120 \mathrm{gm}$ of this sterile feed was transferred to 6 sterile Petri plates with $20 \mathrm{gm}$ in each. The content of each plate was inoculated with $2 \mathrm{ml}$ of $10 \times 10^{5}$ viable spores / $\mathrm{ml}$ of A. fumigatus. Four plates were treated with GC, GE, FE1, \& FE2. The 1st plate was treated with 2 gm of GC, whereas the plates from 2nd -4th were treated with 2. ml of GE, FE1, $\&$ FE2 respectively), while the 5th one was served as control. The last plate was treated with $1 \mathrm{ml}$ antifungal agent (Nystatin solution 100000 I.U./ml, ITALFARMACO, MILANO-ITALY) \& used as positive control. All plates were kept at $28 \mathrm{C}$ for 9 days $\&$ the number of spores per gram of feed was determined after every $48 \mathrm{hr}$ by standard pour plate method. Each test carried out in duplicate (Prassad \& Sharma, 1981 \& Pai \& Platt, 1995)

\section{Results And Discussion}

The observation obtained from investigation of aqueous GE \& FE on $A$. fumigatus have been summarized in table 1 .

It was evident from the table that GE completely inhibited the multiplication of the test fungus whether the extract was placed on the surface of medium or mixed with it. This finding was in agreement with that of Krest \& Keusgen (1999) who stated that garlic contain many active principles which decompose on extraction into variety of substances thus make them as important source of therapeutic agent.

Garlic could be used as an effective dermatophytic agent (Pai \& Platt, $1995) \&$ its extract has clear inhibitory effect against the genus Aspergillus ((Venugopal \& Venugopal, 1995).

The degree of fungal growth inhibition appears to be independent upon the method of testing, thus the inhibitory effect of GE was very similar when used on the surface or mixed with the medium. 
On other hand FE did riot exhibit any inhibitory effect against $A$. fumigatus in the agar plate test as dipicted in Table 1: This finding was in contrast to that of AL-Hassan \& AL- Gailany ( 1985) who mentioned that the seeds of fenugreek are widely used as a cure for many common diseases.

Depending on our knowledge, there is no preliminary data suggest that fenugreek seeds are cabable of being an antifungal agent. Although the method of testing used here is not comprehensive, but virtually the FE did not inhibit fungal growth. So far we have not been successful in identifying possible inhibitory role for this seeds on A. fumigatus. Therefore, diseases cured by fenugreek, as it was suggested by the previous authors, might be caused by agents other than A. fumigatus.

Data presented in Table 2 show that GE as well as GC inhibited the growth of A. fumigatus in poultry feed samples. After $48 \mathrm{hrs}$ of experimentation, the viable spore count of the test fungus per gram of feed sample treated with $\mathrm{CE}$ was less than control feed sample. Inhibition of fungal sporulation, in this study, was in agreement with that of Prassad \& Sharma (1981) who reported that the viable spore count of three test fungi per gram of feed treated with garlic was ten to one hundred times less than control.

The viable spore count found by the same authors was continued to be inhibited for 19 days of incubation. In this study, the viable spore count was increased after 9 days of incubation. This might be due to the decomposition of the volatile products of garlic as well as the difference in tile condition of the experiment.

GE exhibited more effect than GC as indicated from the numbers of viable spore count in Table 2, this might be partly due to uneven mixing of the chips than the extract. Moreover, the amount of the active principle, allicin, released could be less in chips than extract because alliin is converted to allicin by the action of alliinase when garlic cells are ruptured on extraction (Krest \& Keusgen, 1999).

FE did not exhibit any inhibitory effect against the test fungus when inoculated in poultry feed. This result was in concordance with that of Patil et al. (1997) who mentioned that fenugreek seeds are consumed as spices \& also as medicines. Consumption of fenugreek seeds as medicines might not be necessary for treatment of infections.

It should be noted that there was a considerable difference appeared in sensitivity of A. fumigatus agaist GE during the two method of experimentation. This might be due to the direct contact between the GE \& the test fungus in the agar plate method. Moreover, GE might be absorbed during mixing with the feed. 
Because of its availability \& effectiveness against A. fumigatus at 5\% Up to a period of 8 days, it could be concluded that garlic can be considered as feed additive to protect as well as relieve the chickens from fungal infection.

\section{Acknowledgement}

Thanks are due to F. H. Abas \& M. A. Sabih, College of Veterinary Medicine, Basrah, for their aids.

Table 1: Effect of GE \& FE on A. fumigatus

\begin{tabular}{|c|c|c|}
\hline \multirow{2}{*}{ Extract } & \multicolumn{2}{|c|}{$\begin{array}{c}\text { Degree of fungal growth after treatment } \\
\text { with extract }\end{array}$} \\
\cline { 2 - 3 } & On medium surface & With the medium \\
\hline $\mathrm{GE}$ & --- & --- \\
\hline $\mathrm{FE}_{1}$ & +++ & +++ \\
\hline $\mathrm{FE}_{2}$ & +++ & +++ \\
\hline $\begin{array}{c}\text { Nystatin Solution } 100000 \\
\text { I.U/ ml }\end{array}$ & -- & --- \\
\hline Control & +++ & +++ \\
\hline & & \\
\hline
\end{tabular}

- - - Complete growth inhibition.

+++ Full fungal growth

Table 2: Effect of GE \& FE on, A. fumigatus inoculated in poultry feed

\begin{tabular}{|c|c|c|c|c|c|c|}
\hline \multirow{2}{*}{$\begin{array}{c}\text { Day after } \\
\text { inoculation }\end{array}$} & \multicolumn{6}{|c|}{ No. of spores $\mathbf{1 0}$ per gram of poultry feed } \\
\cline { 2 - 7 } & Control & $\begin{array}{c}\mathbf{5 \%} \\
\mathbf{G E}\end{array}$ & $\begin{array}{c}\mathbf{1 0 \%} \\
\mathbf{G C}\end{array}$ & $\begin{array}{c}\mathbf{1 0 \%} \\
\mathbf{F E}_{\mathbf{1}}\end{array}$ & $\begin{array}{c}\mathbf{1 0 \%} \\
\mathbf{F E}_{\mathbf{2}}\end{array}$ & Nystatin solution 100 000 I.U./ $\mathbf{~ m l}$ \\
\hline 2 & 20.3 & 1.4 & 2.5 & 19.9 & 20.1 & 0 \\
\hline 4 & 22.6 & 1.6 & 3.3 & 21.8 & 20.9 & 0 \\
\hline 6 & 80.0 & 1.9 & 4.6 & 78.9 & 79.0 & 0 \\
\hline 8 & 94.2 & 2.2 & 6.1 & 95.0 & 95.0 & 0 \\
\hline
\end{tabular}




\section{References}

1. AI-Hassan, I. A. A \& AI-Gailany, K. A. S (1985). Biochemical studies on the seeds of Trigonella foenum - graceum. JBSR 16(1): 73-81.

2. Appleton, J. A. \& Tansey, M. R. (1975). Inhibition of growth of zoopathogenic fungi by garlic extract. Mycologia. 67: 882 .

3. Basim,F. (1979). Factors influencing the activity of aqueous garlic extract on the death of Staph. aureus. M. Sc. Thesis, Coll. Agr., Univ. Baghdad. Baghdad, Iraq.

4. Carter, G. R. (1984). Diagnostic Procedures in Veterinary Bacteriology \& Mycology. $4^{\text {th }}$ Ed. Charles, C. Thomas. Springfield. 1llinos. U.S. A.

5. Domermuth, C. H. \& Gross, W. B. (1975). Isolation \& identification of Avian Pathogens. $1^{\text {st }}$. Ed. Am. Asso. Av. Pathologists, Texas.

6. El-Kady, I. A.; Mohamad, S. S. \& Eman, M. M. (1993). Antibacterial \& antidermatophyte activities of some essential oils from spices. Qatar Univ. Sci. J. 13(1):63-69.

7. Krest, I. \& Keusgen, M. (1999). Ouality of herbal remedies from Allium sativum : differences between alliinase from garlic powder \& fresh garlic. P1ants Med. 65(2): 139-143.

8. Pai, S.T. \& Platt, M. W. (1995). Antifungal effects of Allium sativum (garlic) extract against the Aspergillus species involved in otomycosis. Appl. Microbiol. 20(1):14-18.

9. Patil, S. P.; Niphadkar, P. V. \& Bapat, M. M. ( 1997). Allergy to fenugreek (Trigonella foenum - graecum). Allergy, Asthma, Immunol. 78(3). 297-300.

10. Prassad, G. \& Sharma, V. D. (1981). Antifungal property of Garlic (Allium sativum) in poultry feed substrate . Poult. Sci. 60: 541-545.

11. Qasem, J. R. (1996). Fungitoxicity of weed extracts to tomato wilt pathogen Fusarium oxysarium s.sp. Lycoperici ). Emir. J. Agric. Sci. 8:103-112.

12. Riggs, D. R.; DeHaven, J. I. \& Lamm, D. L- (1997). Allium sativum (garlic) treatment for murine transitional cell carcinoma. Cancer. 79(10):1987-1994.

13. Venugopal, P. V. \& Venugopal, T. V. (1995). Antidermatophytic activity of garlic (Allium sativum ) in Vitro. Int. J. Dermatol. 34(4): 278-279. 


\title{
Influence of feeding different types feed blocks as supplementary feed on the reproductive performance of Awassi ewes grazing cereal stubble
}

\author{
A. D. Salman* \\ D. A. Ali** \\ Hadeel K. Ibrahim** \\ R. A. Ibrahim* \\ *State Board of Agricultural Research, Ministry of Agriculture. \\ **Dept. of Public Health. College of Veterinary Medicine, Baghdad University.
}

\section{Summary}

This study was conducted to investigate the Influence of feeding different types feed blocks as supplementary feed on the reproductive performance of Awassi ewes grazing cereal stubble. These types were feed blocks enriched with cottonseed meal (CSM) or Brewers' grain (BG) as sources undegradable protein (UDP). Ninety-six Awassi ewes (mean live weight 42.2 Kg), aged 3-4 years were allocated into three groups according to ewes live weight and body condition score.

Group (C): Control (No Supplement) stubble grazing only.

Group (FBC): FB enriched with CSM supplement plus stubble grazing.

Group (FBB): FB enriched with BG supplement plus stubble grazing.

All ewes were run as one flock during cereal stubble grazing. The feed blocks were fed to animals (supplementary groups) after their return from grazing wheat and barley stubble (28 days prior to mating and 54 days after introduction of rams). Rams run with the flock during the mating period. The results showed that feeding feed blocks enriched with CSM and BG as supplementary feed resulted considerable improvement in weight gain $(\mathrm{P}<0.05)$, body condition score $(\mathrm{P}<0.05)$, conception rate $(13-16)$, lambing percentage (25$33 \%)$, twinning percentage (13-18\%) and decreased the proportion of barren ewes (19 vs. 6 and 3\%). Inclusion of small amount of high moisture brewers grain by-product $(9 \%)$ as sources of undegradable protein in the feed blocks formula as replacement for costly cottonseed meal resulted a dramatic effects on the reproductive performance of Awassi ewes especially twinning rates and lambing rate. 
تأثير تغذية أنواع مختلفة من البلوكات العلفية كعلف تكميلي في الأداء التناسلي للنعاج العواسية التي تعتمد في تغذيتها على مخلفات الحصاد للحبوب

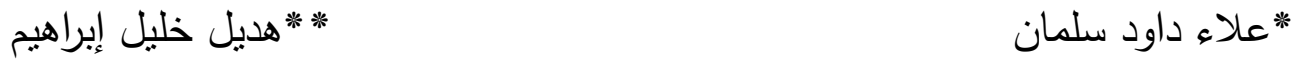

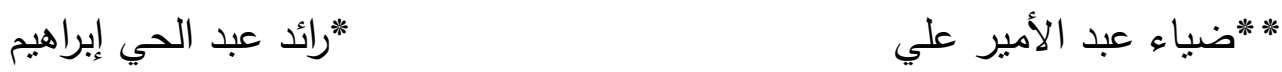

\section{الخلاصة}

أجريت هذه الدراسة بهدف تقيم تأثير تغذية أنواع مختلفة من البلوكات العلفية كعلف تكميلي في

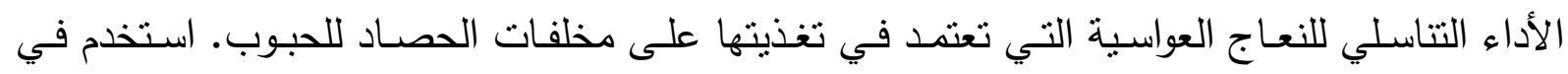
التجربة 90 نعجة عواسية و بعمر 3-4 سنوات و معدل وزن ابتدائي 42.2 كغم وقسمت حسب أوزانها ودرجة حالة جسمها إلى أربعة مجاميع منساوية.

المجموعة (C): التغذية التقليدية (رعي مخلفات الحصاد فقط). المجموعة (FBC): بلوكات علفية مدعمة بكسبة بذور القطن +رعي مخلفات الحصاد.

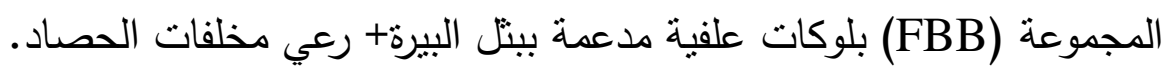

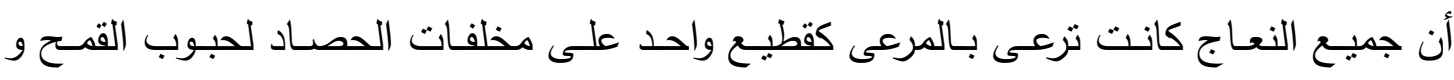

الثعير • ثم تقديم البلوكات العلفية كإضافات علفية للمجموعتين (FBC, FBB) بعد عودة الحيوانات من

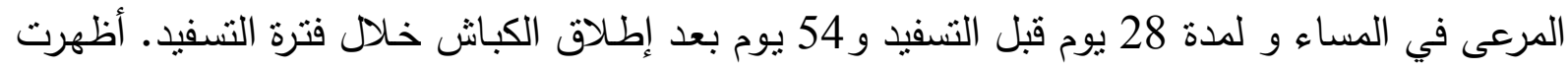

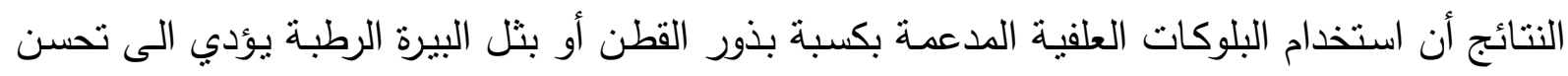

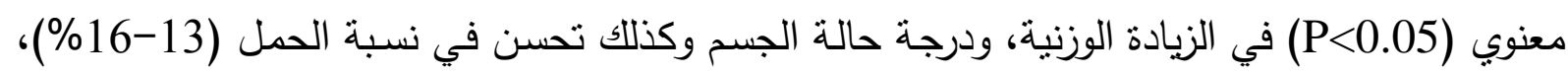

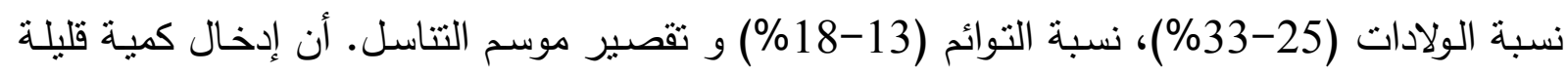
من بتل البيرة الرطبة (9\%) في تركيبة البلوكات العلفية كمصدر للبروتين غير المتحلل في الكرش بدات بديل

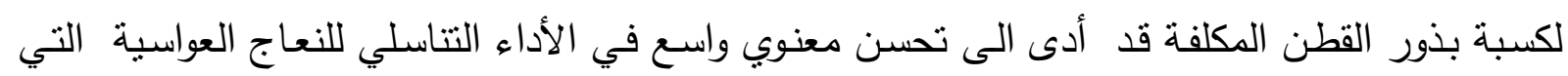
تعتمد في تغذيتها على رعي مخلفات الحصاد للحبوب وخاصة نسبة التوائم والولادات. 


\section{Introduction}

Sheep in Iraq are heavily dependent on cereal (wheat and barley) stubble grazing as their sole source of feed from June to October, a period which coincides with mating season $(1,2)$. Farmer practices that no supplement is given during this time. However, in the early days of grazing in June and July the quality of stubble is high due to shattered grains and spikes which could be adequate to support the animals (3). Stubble quality later becomes poor and inadequate for animal maintenance with regard to protein and minerals requirements $(1,3)$.

Sheep fertility may be affected by fluctuation of nutrient intake and the deficiency of protein and minerals sources $(1,3,4)$. Earlier studies have shown that using ordinary feed blocks as supplementary feed improved the weight gain, conception rates and shortening the mating season of Awassi ewes grazing cereal stubble (5). But twinning percentage was not affected due to feed block supplementation. The importance of protein quality on the reproductive performance of sheep was well documented in the literature (6). It was found that using protein supplements riches in rumen undegradable protein improved the ewes' ovulation rate considerably $(6,7)$. Therefore, series of on-station and on-farm experiments were conducted to investigate the effect of supplementing urea feed blocks enriched with undegradable protein (UDP) and vitamins $\mathrm{AD}_{3} \mathrm{E}$ on the reproductive performance of Awassi ewes' $(4,8,9)$. The results of these experiments showed that when feed blocks enriched with cotton seed meal (source of UDP) resulted in considerable improvement in conception rate, lambing percentage, twinning percentage and cycling activity as compared to the control (non-supplemented groups). However due limited the availability of conventional protein supplements (cotton seed meal and soybean meal) are limited and costly in Iraq and there is difficult to be justified economically (10). High moisture Brewers' grain is a by-product of the brewer factories in Iraq. It is top quality protein (26\%) and good source of UDP (11). Therefore this study was conducted to investigate the effect of using feed blocks enriched with cottonseed meal (CSM) or Brewers' grain (BG) as sources UDP on the reproductive performance of Awassi ewes grazing cereal stubble.

\section{Materials and Methods}

Ninety-six Awassi ewes (mean live weight $42.2 \mathrm{Kg}$ ), aged 3-4 years were allocated into three groups according to ewes live weight and body condition score (BCS).

Group (C): Control (No Supplement).

Group (FBC): FB enriched with CSM supplement. 
Group (FBB): FB enriched with BG S supplement.

All ewes were run as one flock during cereal stubble grazing. The feed blocks were fed to animals (supplementary groups) after their return from grazing wheat and barley stubble (28 days prior to mating and 54 days after introduction of rams). Twelve rams run with the flock during the mating period. Ewes and rams grazed wheat and barley stubble at Fudaliah Research Station (IPA Agriculture Research Center). The formulae of feed blocks used in this experiment and their chemical analysis are presented in Table 1. The cereal stubble was sampled at ground level prior to grazing and on days 30 for chemical analysis (Table 2). The chemical analyses were conducted for experimental diets according to (12). Ewes weight and body condition score (13) were recorded at start, mating and the end of mating. Conception, lambing, twinning rates and the percentage of barren ewes were measured. Statistical analysis was done using GLM procedure of SAS (14). Chi-Square test was used to compare fertility traits.

Table 1: The formulae of feed blocks and their chemical analysis

\begin{tabular}{|l|l|l|}
\hline Ingredients $(\%)$ & Formula $($ FBC) & Formula (FBB) \\
\hline Urea & 5 & 5 \\
\hline Wheat bran & 30 & 30 \\
\hline Rice bran & 20 & 5 \\
\hline Date pulp & - & 15 \\
\hline Poultry litter & 12 & 12 \\
\hline Brewer grain & - & 9 \\
\hline Cotton seed meal & & - \\
\hline Cereal waste & 8 & 8 \\
\hline Cao & 12 & 10 \\
\hline CaSO4 & 1 & 1 \\
\hline Salt & 5 & 5 \\
\hline Chemical analysis & $\%$ & $\%$ \\
\hline DM & 95.32 & 94.68 \\
\hline CP & 18.15 & 19.31 \\
\hline EE & 1.39 & 1.44 \\
\hline CF & 13.79 & 9.79 \\
\hline Ash & 28.55 & 32.76 \\
\hline & & \\
\hline
\end{tabular}




\section{Results and Discussion}

The nutritive value of the cereal stubble (Table 2) indicated and confirmed other studies $(3,15)$ to the importance of using supplementary feed for sheep during cereal stubble grazing.

Table 2: Chemical analysis of cereal stubble

\begin{tabular}{|l|l|l|}
\hline & At Start (\%) & At 30 Days (\%) \\
\hline DM & 93.95 & 95.02 \\
\hline CP & 6.78 & 4.90 \\
\hline Ash & 13.35 & 14.54 \\
\hline GE & 17.29 & 16.42 \\
\hline
\end{tabular}

The results of the effect of feed block supplementation on weight changes and body condition score of Awassi ewes grazing cereal stubble are presented in Table 3. These results showed that feeding Awassi ewes feed blocks (Table 3) during cereal stubble grazing improved significantly $(\mathrm{P}<0.5)$ their weight gain as compared to control group (C). The supplemented groups (FBC and FBB) had higher mating and final weights as compared with control group (C). The present result confirmed previous studies conducted in $\operatorname{Iraq}(1,4,5)$ and elsewhere in the region $(3,15)$. These results indicated that feed blocks improved the weight gain of ewes dependent on low quality forages as their main diet $(16,17)$. This improvement in ewes' weight gain is mainly because using feed blocks as supplementary feed would improve the efficiency of utilization of the crop residues by supplying the deficient nutrients (protein and minerals) and then improve the rumen ecosystem for fermentative digestion (17). Similar trends were observed on the effects of feed blocks on ewes' body condition score (Table 3). The body condition score of supplemented groups (FBC and FBB) at mating were slightly higher $(\mathrm{P}>0.05)$ than non-supplemented group. The final ewes' body condition of supplemented groups were significantly higher $(\mathrm{P}<0.05)$ than non-supplemented group. The body condition scores were 2.52, 2.87 and 2.75 for groups C, FBC, and FBB respectively. The present results are in agreement with other studies, $(3,4,8)$ which showed that using feed blocks or cottonseed meal as protein supplement could improve in the body condition of Awassi ewes grazing cereal stubble. Despite the two types of feed blocks were formulated to have similar protein contents (Table 2), but the intake of FBB type was slightly higher (8\%). It is found recently that inclusion high moisture by-products (e.g. date pulp, brewer grains and sugar beet pulp) in feed blocks manufacturing gave top quality feed blocks regarding compactness and hardness and also improve palatability of feed blocks $(1,8)$. 
Table 3: Effect of feed block supplementation on weight, weight changes and body condition score of Awassi ewes grazing cereal stubble.

\begin{tabular}{|l|l|l|l|}
\hline Measurements & $\mathrm{C}$ & FBC & FBB \\
\hline No. of ewes & 32 & 32 & 31 \\
\hline Initial weight $(\mathrm{kg})$ & $42.10 \mathrm{a}$ & $42.88 \mathrm{a}$ & $42.40 \mathrm{a}$ \\
\hline Mating weight $(\mathrm{kg})$ & $43.37 \mathrm{a}$ & $45.21 \mathrm{a}$ & $44.70 \mathrm{a}$ \\
\hline Final weight $(\mathrm{kg})$ & $42.40 \mathrm{a}$ & $45.60 \mathrm{~b}$ & $44.50 \mathrm{ab}$ \\
\hline Weight gain $(\mathrm{g} /$ day/ewe) & $3 \mathrm{a}$ & $33 \mathrm{~b}$ & $26 \mathrm{~b}$ \\
\hline Initial body condition score & $2.25 \mathrm{a}$ & $2.20 \mathrm{a}$ & $2.18 \mathrm{a}$ \\
\hline Mating body condition score & $2.42 \mathrm{a}$ & $2.50 \mathrm{a}$ & $2.52 \mathrm{a}$ \\
\hline Final body condition score & $2.52 \mathrm{a}$ & $2.87 \mathrm{~b}$ & $2.75 \mathrm{ab}$ \\
\hline Feed block intake (g/day/ewe) & - & 259 & 280 \\
\hline
\end{tabular}

Mean with different superscript for each trait differ significantly $(\mathrm{P}<0.05)$.

The effect of enrichment feed blocks with different sources of undegradable on the reproductive performance of Awassi ewes are presented in Table 4. These results showed that the reproductive performance of Awassi ewes grazing cereal improved considerably due feed block supplementation. The percent of ewes lambed after mating during the first and second estrus cycles were significantly higher $(\mathrm{P}<0.05)$ in supplemented groups $(\mathrm{FBC}$ and FBB) than non-supplemented group (C). The percent of ewes lambed in first cycle were $35 \%, 80 \%$ and $73 \%$ for groups C, FBC and FBB respectively. This result confirm other results which indicated that using feed blocks or cottonseed cake supplementation during mating season had resulted in higher number of Awassi ewes mated in the first and second estrous cycle $(1,3,4,9)$. This improvement in cycling activity of supplemented groups was mainly due to premating supplementation (4). These results (Table 4) also showed that when feed blocks enriched with cottonseed cake and brewer grain resulted considerable improvement in conception rate (13-16), lambing percentage (25-33\%), twinning percentage (13-18\%) and decreased the proportion of barren ewes (19 vs. 6 and 3\%) compared with control group. The present results showed a similar trend to previous experiments, but the performance of the supplemented groups were relatively higher than the results obtained by other studies $(5,9)$. This can be attributed to the importance of feeding undegradable protein in improving ruminants productivity, which depend on crop residues as basal diet (17). The latter study showed that a small amount of protein that is directly available to the animal (i.e. undegradable protein) stimulates both productivity and efficiency of feed utilization. 
Table 4: Effect of feed block supplementation on reproductive performance of Awassi ewes grazing cereal stubble.

\begin{tabular}{|l|l|c|c|c|}
\hline Treats & C & FBC & FBB & Significance \\
\hline $\begin{array}{l}\text { No. of ewes exposed to } \\
\text { rams }\end{array}$ & 32 & 32 & 31 & \\
\hline No. of ewes lambed & 26 & 30 & 30 & \\
\hline Ewes lambed 1 & & & \\
\hline Ewes lambed 2 $^{\text {nd }}$ cycle (\%) & 35 & 80 & 73 & $\mathrm{P}<0.05$ \\
\hline Ewes lambed 3 & 61 & 20 & 24 & $\mathrm{P}<0.05$ \\
\hline Conception rate $^{\mathrm{a}}(\%)$ & 81 & 94 & 97 & $\mathrm{NS}$ \\
\hline Lambing $^{\mathrm{b}}(\%)$ & 4 & 0 & 117 & $\mathrm{P}<0.05$ \\
\hline Twinning $^{\mathrm{c}}(\%)$ & 84 & 109 & 1105 \\
\hline Barren ewes $^{\mathrm{d}}(\%)$ & 19 & 6 & 3 & $\mathrm{P}<0.05$ \\
\hline
\end{tabular}

${ }^{a}$ Number of ewes lambed/number of ewes joined.

${ }^{\mathrm{b}}$ Number of lambs born/ number of ewes joined.

${ }^{\mathrm{c}}$ Number of ewes giving twin/ number of ewes joined.

${ }^{\mathrm{d}}$ Number of ewes not lambed/ number of ewes joined.

It can be concluded that inclusion of small amount of high moisture brewers grain by-product (9\%) as sources of undegradable protein in the feed blocks formula as replacement for costly cottonseed meal resulted a drastic effects on the reproductive performance of Awassi ewes especially twinning rates and lambing rate. Also the use of UDP in feed blocks may indicate the low cost of such practice compared to other technologies such as flushing and hormonal treatment $(18,19)$.

\section{References}

1. Salman, A. D.(1996). The role of multinutrient blocks for sheep production in integrated cereal-livestock farming system in Iraq. Second FAO Electronic Conference in Tropical Feeds, Livestock Feed Resources within Integrated Farming System. 1st Sept 1996-1st Feb 1997.

2. Al-Haboby, A. H.; Shideed, K. H. and Khatab, G. K. (1997). Sheep fertility in Iraq. Sacia-economic group meeting for the Mashreq countries in the Mashreq/Maghreb Project. March, 24-27, Amman, Jordan.

3. Treacher, T.T.; Rihawi, S. and Owen, E. (1997). Utilization of barley stubble by Awassi sheep. In: Haddad, N., Tutwiler, R., Thomson, E. (Eds.), Improvement of Crop-Livestock Integration Systems in West Asia and North Africa. Proceedings of the Regional Symposium on Integrated Crop- 
Livestock Systems in Dry Areas of West Asia and North Africa Amman, Jordan. ICARDA, Aleppo, Syria, November 6-8, 1995.

4. Al-Haboby, A.H., Salman, A.D. and Abdul Kareem, T.A. 1999. Influence of protein supplementation on reproductive traits of Awassi sheep grazing cereal stubble Small Ruminant Research, 34:33-40.

5. Salman, A.D. 1998. Effect of feed blocks supplementation on the reproductive performance of Awassi ewes grazing cereal stubble. International Symposium" Livestock Production in Climatic Uncertainty in the Mediterranean. ANPA, EAAP, CIHEAM and FAO. 22-24 October 1998. Agadir-Morocco.

6. Smith, J. F and Stewart, P. D (1990). Effects of nutrition on the ovulation rate of ewes. Concepts and consequences. In: Reproductive Physiology of Merino Sheep, Oldham, C. M., Martin, G. B. and Purvis, I. W. (eds). Univ. of West Australia, Perth, pp. 85-101.

7. Marshall, T.; Croker, K. P. and Lightfoot, R. J. (1979). Age of ewes and response to lupins: Effect of lupin supplementation on ovulation rate. Studies in the agriculture and food sciences. In: Sheep Breeding (Eds.G.J.Tomes, D. E. Robertson and R. J. Lightfoot.), $2^{\text {nd }}$ edn. Butterworths \& Co.Publ., London, UK. pp. 367-371.

8. Salman, A.D. and Mamdouh, Q. 1999. Feed blocks supplementation as a hedging strategy under drought condition. Sixth International Conference on the Development of Dry lands. Development challenges Beyond the year 2000. IDDC, ICARDA, 22-27, August 1999, Cairo, Egypt.

9. Ibrahim, H. K. 1999. The effect of supplementary feed on the reproductive performance of Awassi sheep. M. Sc. Thesis. College of Veterinary Medicin, University of Baghdad.

10. Shideed, K.H and Salman, A.D. 1997. Production utilization, Economic assessment and adoption of by-products feed blocks in Iraq. Regional consultancy report. ICARDA. Mashreq/ Maghreb project (The development of integrated crop-livestock production systems in West Asia and North Africa).

11. Hadjipanyaiotou, M., 1997.The role of crop residues and agro- industrial by-products in filling the deficit of animal feedstuffs in the Middle East. In: Haddad, N., Tutwiler, R., Thomson, E. (Eds.), Improvement of CropLivestock Integration Systems in West Asia and North Africa. Proceedings of the Regional Symposium on Integrated Crop-Livestock Systems in Dry Areas of West Asia and North Africa, Amman, Jordan. ICARDA, Aleppo, Syria, November 6-8, 1995.

12. Association of Official Analytical Chemists (AOAC) (1984). Official methods of analysis $14^{\text {th }}$, Ed. Association of official chemists. Washington, D. C., USA. 
13. Meat and Livestock Commission (MLC). (1988). Feeding the Ewe. Sheep Improvement Service. Tech. Rep. No.2. Bletchely, Bucks. UK.

14. SAS.(1989) User's Guide: Statistics. SAS Inst. Inc. Cary, NC.

15. Guessous, F.; Luginbuhl, J. M.; Rihani, N. and Pond, K. R. (1991). Influences of supplementation on the performance of gestating ewes grazing wheat stubble pastures. Anim. Feed. Sci. and Technol. 45:95- 103.

16. Habib G., Basit Ali Shah S., Wahidullah G. and Ghuffranullah. 1991. The importance of urea-molasses blocks and by-pass protein in animal production. The situation in Pakistan. 133-145. In Isotope and Related Techniques in Animal Production and Health by International Atomic Energy. Vienna.

17. Hendratno, C., Nalan, J. V. and Leng. R. A. 1991. The importance of ureamolasses multinutrient blocks for ruminant production in Indonesia. 157169. In Isotope and Related Techniques in Animal Production and Health by International Atomic Energy Agency. Vienna.

18. Younis, A. A., Al-Kamali, A. A. and El-Tawill, E. A. 1978. Effect of flushing on fertility of Awassi and Hamdani ewes. Wld. Rev. Anim. Prod. 14: 41-48.

19. Al-Rawi, A. A.; Al-Haboby, A. H. and Al-Salman, M. H. 1997. Small ruminants breeding and reproductive physiology research and technology transfer in Iraq. ICARDA. Mashreq/Maghreb Project (The Development of Integrated Crop-Livestock Production Systems in West Asia and North Africa). 